\title{
Forms of Melanoplus bowditchi (Orthoptera: Acrididae) collected from different host plants are indistinguishable genetically and in aedeagal morphology
}

The sagebrush grasshopper, Melanoplus bowditchi Scudder (Orthoptera: Acrididae), is a phytophilous species that is widely distributed in the western United States on sagebrush species. The geographical distribution of $M$. bowditchi is very similar to the range of its host plants and its feeding association varies in relation to sagebrush distribution. Melanoplus bowditchi bowditchi Scudder and M. bowditchi canus Hebard were described based on their feeding association with different sagebrush species, sand sagebrush and silver sagebrush, respectively. Recently, $M$. bowditchi have been observed feeding on other plant species in western Nebraska. We collected adult M. bowditchi feeding on four plant species, sand sagebrush, Artemisia filifolia, big sagebrush, $A$. tridentata, fringed sagebrush, $A$. frigidus, and winterfat, Krascheninnikovia lanata. We compared the specimens collected from the four plant species for their morphological and genetic differences. We observed no consistent differences among the aedeagal parameres or basal rings among the grasshoppers collected from different host plants. Amplified Fragment Length Polymorphism markers were used to test the genetic relationships among the grasshoppers. Analysis of Molecular Variance and distance-based Unweighted Pair Group Method with Arithmetic mean dendrogram failed to reveal significant differences. Although the forms showed behavioral and minor color and size differences, the genetic data suggest all forms under study likely interbreed, which indicates they are a single species instead of four species or subspecies. These results indicate that host plant use may influence melanopline phenotype and suggest the need of further genetic analysis of subspecies recognized based on morphology, distribution, and ecology. 
Corresponding Author

W. Wyatt Hoback

Department of Biology, Bruner Hall of Science University of Nebraska at Kearney $240111^{\text {th }}$ Avenue, Kearney, NE 68849

hobackww@unk.edu

Phone: (308) 865-8602

Fax: (308) 865-8045

\title{
Forms of Melanoplus bowditchi (Orthoptera: Acrididae) collected from different host plants
} are indistinguishable genetically and in aedeagal morphology

\author{
MUHAMMAD IRFAN ULLAH ${ }^{1}$, FATIMA MUSTAFA ${ }^{1}$, KATE M. KNEELAND ${ }^{1}$, MATHEW L. BRUST², W. \\ WYATT HOBACK 3 , SHRIPAT T. KAMBLE ${ }^{1}$ AND JOHN E. FOSTER ${ }^{1}$ \\ ${ }^{1}$ Department of Entomology, University of Nebraska, Lincoln, NE 68583 \\ ${ }^{2}$ Department of Biology, Chadron State College, Chadron, NE 69337 \\ ${ }^{3}$ Department of Biology, University of Nebraska, Kearney, NE 68849

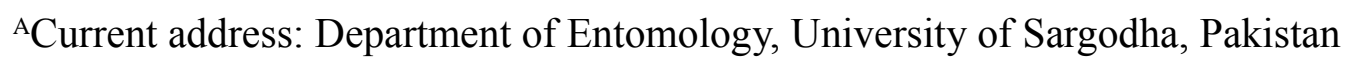 \\ BUniversity of Agriculture Faisalabad, Pakistan
}


Melanoplus bowditchi, morphological variation, host plant, deme, ecotype, AFLP

21

\section{Introduction}

As a group, grasshoppers are somewhat unusual among herbivorous insects in that most are polyphagous, feeding selectively on plants from a number of unrelated plant families (Otte \& Joern 1977). Because of their polyphagy, most grasshopper species are not expected to experience disruptive selection associated with host choice. There are, however, some grasshopper species with restricted host ranges and a small number that are truly host specific (Otte \& Joern 1977, Sword \& Dopman 1999). Host specific grasshoppers also show differences in development rates, lifespan, and size relating to host use (Traxler \& Joern 1999). In addition, host plant-associated genetic differences have also been observed in the study of Hesperotettix viridis (Thomas) and Schistocera lineata Scudder (Sword et al. 2005).

The sagebrush grasshopper, Melanoplus bowditchi Scudder, was described by Scudder in 1878 (Scudder 1897). This grasshopper is a phytophilous species that is widely distributed in the grasslands of the western United States. Although it occurs in mixed-grass, shortgrass, desert shrub and bunchgrass prairies, it feeds almost exclusively on sagebrush species (Mulkern et al. 1969) and its distribution is dependent on sagebrush plants. Six host plants are identified for $M$. bowditchi in Pfadt (1994), with the primary hosts being silver sagebrush, Artemesia cana, and sand sagebrush, A. filifolia. The other four species of sagebrush, along with silver sagebrush, are found in mixed-grass prairie and are reportedly consumed in minute quantities by M. bowditchi (Pfadt 1994). The species is potentially damaging, especially for silver sagebrush (Pfadt 1994). While silver sagebrush, is broadly distributed through western North America, sand sagebrush, Artemisia filifolia Torrey, is usually associated with deep sand deposits and serves as the host plant for M. bowditchi in areas where silver sagebrush is limited (Harvey 1981). 
description of Melanoplus bowditchi canus Hebard (Hebard 1925). The original series of M. bowditchi bowditchi was found feeding on A. filifolia, while M. bowditchi canus was collected from big sagebrush, Artemisia tridentata (Hebard 1925). Melanoplus bowditchi canus is usually dark gray in color and is common in the northern Great Plains. Its preferred food plant is silver sagebrush, although it has also been observed feeding on other sagebrush species. It is normally found on taller plants until after oviposition, when it becomes abundant on shorter plants. It is seldom found on the ground (Anderson \& Wright 1952). In comparison to M. bowditchi canus, M. bowditchi bowditchi has a larger body size, brighter yellow and brown colors, and very clear tegmina (Hebard 1925).

Hebard (1925) suggested that the gray patterned coloration of M. bowditchi canus was a result of a close relationship to the Melanoplus cinereus group rather than to other forms of the Melanoplus flavidus group (Hebard 1925). However, geographical differences in host plant use and morphology might also be the result of environmentally triggered variation among populations. For example, for a specialized flea beetle, areas with abundant hosts and frequent oviposition show a high level of host acceptance resulting in less use of low-ranking hosts (Tahvanainen \& Root 1972). Where preferred plants are uncommon or their availability is obscured by related members of the plant community, thresholds for host acceptance are expected to fall, making the use of other plants more likely (Stanton \& Cook 1983, Wiklund 1975). Recent observations have revealed adult M. bowditchi feeding on other Artemisia species and winterfat, Krascheninnikovia lanata. These forms seem to be distinct in both size and color patterns (Fig. 1) and exhibit behavioral differences. Specimens of M. bowditchi collected from fringed sagebrush, Artemisia frigida are exceptionally pallid (Fig. 1) ranging from a pale tan to pale gray and superficially resembling Melanoplus angustipennis (Dodge). In addition, 
67 specimens collected from fringed sagebrush are more reluctant to jump than $M$. bowditchi

68 bowditchi and often must be knocked from the small shrubs to be revealed, similar to reports for

69 M. bowditchi canus. Fringed sagebrush is common in dry, well-drained soils or in disturbed

70 areas. In mixed-grass prairie it is found with western wheatgrass Pascopyrum smithii, blue grama

71 Bouteloua gracilis, and winterfat.

84 Pfadt (2002) and Brust et al. (2008). from each plant species were examined (Table 1). In each case, the terminal part of the abdomen

87 was separated, intestinal contents removed, and the remaining structure soaked in a solution of 5

$88 \% \mathrm{NaOH}$ for $8-10 \mathrm{~h}$, transferred to $70 \%$ ethanol for $10 \mathrm{~min}$., and the aedeagi removed. Aedeagi 
were cleaned under a dissecting microscope to remove connective tissue. They were preserved in $70 \%$ ethanol until examination. Photographs of aedeagi were taken through a dissecting microscope. A visual comparison was made of the structure of the terminal end of the aedeagus, and of the paramere structures.

Genetic analysis - Extraction and Quantification of DNA.-The locations, date of collection, number of specimens and plants from which specimens were collected for genetic analysis are presented in Table 2. Hind femora of specimens from each host plant were preserved in $95 \%$ ethanol and stored at $-80{ }^{\circ} \mathrm{C}$ prior to genetic studies. A total of 35 grasshoppers were examined for genetic differences (Table 2). DNA was isolated from the hind femur of each form specimen using acetyletrimethylammonium bromide (CTAB) extraction protocol modified from Doyle \& Doyle (1987). Each hind femur was placed in an autoclaved $1.5 \mathrm{ml} \mathrm{microcentrifuge} \mathrm{tube} \mathrm{and}$ rinsed for $10 \mathrm{~min}$ in Nanopure ${ }^{\circledR}$ water. The entire hind femur was homogenized in $250 \mu 1$ CTAB buffer (100 mM Tris-HCl, $1.4 \mathrm{M} \mathrm{NaCl}, 0.02 \mathrm{M}$ EDTA, $2 \% \mathrm{CTAB}$, and $0.2 \% \beta$ mercaptoethanol) using sterile white quartz sand and plastic pestles. Another $250 \mu 1$ of CTAB was added to the tubes to make a volume of $500 \mu \mathrm{l}$. RNase A (15 $\mu 1$ of $\left.0.05 \mathrm{~g} \mathrm{ml}^{-1}\right)$ was added to each tube, and incubated for $2 \mathrm{~h}$ at $65^{\circ} \mathrm{C}$. Proteinase $\mathrm{K}\left(15 \mu \mathrm{lof} 0.02 \mathrm{~g} \mathrm{ml}^{-1}\right)$ was added, and incubated for $1 \mathrm{~h}$ at $37^{\circ} \mathrm{C}$. Samples were centrifuged for $5 \mathrm{~min}$ at $20^{\circ} \mathrm{C}$ and $12,000 \mathrm{rpm}$. The supernatant from each tube was transferred to new autoclaved tubes and the tissue discarded. Chloroform: isoamyl alcohol $(24: 1)(500 \mu 1)$ was added to the supernatant, and tubes were centrifuged at room temperature for $20 \mathrm{~min}$ at 12,000 rpm. The upper aqueous layer was transferred to new $1.5 \mathrm{ml}$ Eppendorf tubes and the chloroform: isoamyl alcohol step was repeated to isolate the refined top aqueous phase. Chilled isopropanol $\left(400 \mu 1,-20^{\circ} \mathrm{C}\right)$ was added to the tubes to precipitate the DNA, and samples were stored over night at $4^{\circ} \mathrm{C}$. 
113 bottom of the tube. The supernatant was discarded, and the DNA was washed with $400 \mu 1$ of

114 chilled absolute ethanol followed by centrifugation for $5 \mathrm{~min}$. The supernatant was decanted and

115 the wash was repeated using 70\% ethanol. Tubes were centrifuged again for $5 \mathrm{~min}$, then the

116 ethanol was removed and the samples allowed to air dry. The pelleted DNA was suspended in 50

$117 \mu$ l autoclaved 1x TE buffer (10 mM Tris-HCL, $0.1 \mathrm{mM}$ EDTA).

118 AFLP-PCR methods for genetic analysis.-The Amplified Fragment Length Polymorphism

119 (AFLP) technique, modified from Vos et al. (1995) was used for DNA analysis. AFLP consisted

120 of digestion using MseI and EcoRI restriction enzymes, ligation of specific nucleotide adapters, a

121 preselective amplification using universal primers, and a selective amplification using specific

122 primer pairs.

Template preparation.- Restriction digestion was performed using $1.25 \mu 1$ NEB Buffer 4 (New

124 England Biolabs, Foster City, CA), $0.125 \mu$ l bovine serum albumin (New England Biolabs),

$\sim 20 \mathrm{ng} / \mu \mathrm{l}$ DNA template for a total volume of $12.5 \mu \mathrm{l}$. The restriction digestion was incubated on

A ligation mixture $(5 \mu \mathrm{l})$ consisting of $0.5 \mu \mathrm{l} E c o$ RI and $M s e I$ prepared adapters, (Integrated DNA

Technologies, Coralville, IA, USA), $0.5 \mu 1$ T4 DNA ligase, $0.15 \mu 1$ 10x T4 DNA ligase buffer

130 (New England Biolabs), and $3.35 \mu 1$ Nanopure ${ }^{\circledR}$ water was dispensed into the tubes containing

131 the digestion product and incubated at $25^{\circ} \mathrm{C}$ for $8 \mathrm{~h}$. The ligation product was then diluted using

$132135 \mu \mathrm{l}$ of 1x TE buffer. A Nanodrop ${ }^{\circledR}$ spectrophotometer (Thermo Fisher Scientific, Walltham,

133 MA, USA) was used to determine the quantity and quality of DNA in $\mathrm{ng} / \mu \mathrm{l}$ from each tube. 
134 Preamplification.-A preamplification mix consisting of $10 \mu 1$ Preamlification Primer Mix II (LI135 COR Biosciences, Lincoln NE, USA), $0.25 \mu$ 1 Amplitaq 360 DNA polymerase, $0.75 \mu 125 \mathrm{mM}$ $136 \mathrm{MgCl}_{2}$, and $1.25 \mu \mathrm{l}$ 10x PCR buffer II (Applied Biosystems, Foster City, CA) was mixed with $1371.25 \mu \mathrm{l}$ of ligation product and run on a PCR program of 20 cycles $\left(30 \mathrm{~s}\right.$ at $94{ }^{\circ} \mathrm{C}, 1 \mathrm{~min}$ at $56{ }^{\circ} \mathrm{C}$, 138 and 1 min at $72{ }^{\circ} \mathrm{C}$ ), then stored at $4{ }^{\circ} \mathrm{C}$. Nanopure ${ }^{\circledR}$ water was used to dilute the product to a 139 ratio of 1:20. Nucleotide sequences of adapters, preamplification primers and selective primers 140 tested are shown in Table 3. A combination of different primer sets was tested and the best 141 working primer sets for grasshopper DNA were chosen (Table 4).

142 Selective amplification.-The selective PCR mix was prepared consisting of $1.2 \mu 1$ 10x PCR 143 buffer II, $0.72 \mu 125 \mathrm{mM} \mathrm{MgCl}_{2}, 0.24 \mu \mathrm{l}(10 \mathrm{mM})$ deoxynucleotide triphosphate mix, $0.07 \mu \mathrm{l}$ 144 Amplitaq 360 DNA polymerase (Applied Biosystems), $0.5 \mu 1$ of $M$ sel primer $(5.0 \mu \mathrm{M}), 0.3 \mu 1$ 145 EcoRI $(1.0 \mu \mathrm{M})$ IRD-700 labeled primer (Integrated DNA Technologies, Coralville, IA), $6.97 \mu 1$ 146 nanopure ${ }^{\circledR}$ water, and $1.5 \mu 1$ of the preamplification template DNA. This step was performed in 147 the dark due to light sensitivity of the labeled primers. Selective amplification was performed on 148 a GeneAmp 2720 thermal cycler (Applied Biosystems) with one pre-PCR cycle (30 s at $94{ }^{\circ} \mathrm{C}, 30$ $149 \mathrm{~s}$ at $65{ }^{\circ} \mathrm{C}, 1 \mathrm{~min}$ at $\left.72{ }^{\circ} \mathrm{C}\right), 12$ cycles of $30 \mathrm{~s}$ at $94{ }^{\circ} \mathrm{C}, 30 \mathrm{~s}$ at $65^{\circ} \mathrm{C} \rightarrow 56{ }^{\circ} \mathrm{C}, 60 \mathrm{~s}$ at $72{ }^{\circ} \mathrm{C}$, and 23 150 cycles of $30 \mathrm{~s}$ at $94{ }^{\circ} \mathrm{C}, 30 \mathrm{~s}$ at $65{ }^{\circ} \mathrm{C} \rightarrow 56^{\circ} \mathrm{C}$ and $60 \mathrm{~s}$ at $72{ }^{\circ} \mathrm{C}$. Blue stop solution (LI-COR 151 Biosciences, Lincoln, NE) $(2.5 \mu \mathrm{l})$ was used to end the reaction. The product was then denatured 152 for 3 min at $94{ }^{\circ} \mathrm{C}$ and stored at $-20^{\circ} \mathrm{C}$.

153 Data scoring and analysis.-The amplified DNA was electrophoresed in $K B^{\text {plus }} 6.5 \%$ 154 polyacrylamide gel on a GeneReader 4200 DNA analyzer (LI-COR Biosciences) which detects 
155

156

157

158

159

160

161

162

163

164

165

166

167

168

169

170

171

172

173

174

bands through infrared inflorescence. An IRDye-700 labeled 50-700 bp size standard was used to estimate fragment size. The correlation of $\%$ coefficient of variation and the total number of markers was estimated using Bootsie (Foster unpublished).

Gels were scored on Saga Generation 2 version 3.3.0 software (LI-COR Biosciences).

Data were converted to a binary matrix for analysis, with $1=$ presence of a band and $0=$ absence of band. Data were analyzed using Arlequin version 3.5 (Excoffier \& Lischer, 2010) and Popgene version 1.32 (Yeh et al. 1999). Phylogenetic relationships were examined using distance-based methods for the different host associated M. bowditchi. An Unweighted Pair Group Method with Arithmetic mean (UPGMA) dendrogram was constructed using presence/absence characters with the software package PAUP* version 4.0beta (Swofford 2001). Bootstrapping was performed with 1,000 replicates.

\section{Results}

Aedeagus examination.-All examined grasshoppers collected from different host plants had similar aedeagi. The structure and angle of parameres were similar among specimens (Figs. 2 and 3). The mean $( \pm 1$ S.E. $)$ paramere lengths $(0.81 \pm 0.07 \mathrm{~mm})$ were shortest in grasshoppers collected from fringed sagebrush and longest in grasshoppers collected from winterfat $(0.98 \pm$ $0.02 \mathrm{~mm}$ ); however, differences were not significant (ANOVA, $\mathrm{P}=0.085$ ). Aedeagal lengths were also not significantly different, although specimens collected from sand sagebrush had a mean length of $0.81+0.02 \mathrm{~mm}$ compared to_those from winterfat, which had a mean length of $0.63 \pm 0.02 \mathrm{~mm}($ ANOVA, $\mathrm{P}=0.054)$

175 Genetic variation study.-The M. bowditchi from different host plants were initially screened for 176 a total of 10 primer pairs of which six primer pairs (Table 4) were used for analysis. A total of 
177469 markers were scored using the six primer pairs and $63 \%$ of the loci were polymorphic. Using

178 Bootsie examination (J. Foster, unpublished), approximately $96 \%$ of the variation in the $M$.

179 bowditchi populations was captured with the chosen markers.

180 A dendrogram was constructed using a distance-based Unweighted Pair Group Method

181 with Arithmetic mean (UPGMA). The UPGMA analysis did not reveal significant genetic

182 structure differences among the $M$. bowditchi collected from different host plants and there were

183 few nodes with bootstrap values greater than 70\% (Fig. 4). The molecular sequences of

184 grasshoppers collected from winterfat were spread across the dendrogram (Fig. 4).

The M. bowditchi populations were arranged in two groups based on host plant

associations and descriptions of recognized subspecies (Hebard 1925, Pfadt 1994). Grasshoppers

187 collected from winterfat were paired with those collected from fringed sagebrush (the

188 Melanoplus bowditchii canus group) and those collected from fringed sagebrush were paired with 189 those collected from sand sagebrush (the Melanoplus bowditchi bowditchi group). The AMOVA 190 showed the majority of molecular variation (86.8\%) occurred within populations (Table 5). Only

$1917.9 \%$ of the genetic variation occurred among populations within groups while the remaining

$1925.3 \%$ was due to the variation among groups (Table 6). Nei’s $(1987)$ gene diversity $\left(\mathrm{G}_{\mathrm{ST}}\right)$ is

193 described as the coefficient of gene differentiation, while fixation index $\left(\mathrm{F}_{\mathrm{ST}}\right)$ is the measure of 194 differentiation in sub-populations and is only applicable when there are only 2 alleles at a locus.

195 Nei's genetic diversity $\left(\mathrm{G}_{\mathrm{ST}}\right)$ is analogous to Wright's genetic divergence $\left(\mathrm{F}_{\mathrm{ST}}\right)$. $\mathrm{G}_{\mathrm{ST}}$ measures the 196 degree of differentiation in multiple populations. The genetic divergence $\left(\mathrm{F}_{\mathrm{ST}}\right)$ and gene diversity 197 (GST) were low (0.1320 and 0.0879 respectively) while the Nm values (5.1905) were high (Table 198 6) indicating extensive gene flow among populations.

199 Discussion 
201 populations, although they utilize a number of host plants across their range (Futuyma \& Peterson 202 1985, Thompson 1994). This phenomenon is only occasionally reported for grasshoppers (Sword

203 \& Dopman 1999). The sagebrush grasshopper, M. bowditchi, feeds on several species of 204 sagebrush, although $A$. cana and A. filifolia serve as the main host plants (Mulkern et al. 1969, 205 Pfadt 1994). The M. bowditchii subspecies differ somewhat in distribution, with M. bowditchi 206 bowditchi found in the southern grass plains and $M$. bowditchi canus found in the northern 207 sagebrush plains, while the ranges broadly overlap in Wyoming and southwestern South Dakota 208 (Hebard 1929). The geographical distribution of the host plants is very similar to the range of the subspecies of M. bowditchi (Pfadt 1994), and the feeding preference of this grasshopper has been shown to vary based on local plant availability. Examination of the crop content of M. bowditchi collected from North Dakota showed feeding on silver sagebrush, while the populations from western Nebraska ate sand sagebrush (Pfadt 1994). Even though there are some differences in distribution, color, size, and host use between the two described subspecies of M. bowditchi, it is important to question the rationale of naming a subspecies solely on these characteristics. Further, it is important to test if $M$. bowditchi feeding on other host plants represent cryptic species or additional subspecies. different plant species where other host plants were not present. Specimens exhibited behavioral differences and slight color and size differences consistent with previous descriptions of subspecies (Figure 1). Grasshoppers collected from sand sagebrush and winterfat were both very

221 active, either jumping and flying to another host plant when approached within two meters or actively moving into the basal branches. In contrast, specimens collected from fringed sagebrush 
generally did not fly far and had to be disturbed before they jumped or flew. Individuals found

224 feeding on big sagebrush were more sedentary than most other Melanoplus forms (M. Brust, pers. obs). In our examination of male genitalia, we did not find consistent differences. We recognize that we had a small sample size and that a series of more individuals from each host would be better. However, among our samples, the aedeagi appeared similar and there were no significant differences in overall length or paramere angle or lengths (Figs. 2 and 3) suggesting that they are physically able to interbreed. Even if morphological differences had been noted, breeding tests would be required as variation in aedeagi occurs among individuals of a species and support for the hypothesis of genitalic incompatibility among species is controversial (Eberhard et al. 1998, Masty 2012). Thus, genetic testing of gene flow can aid in determining the presence of populations and incipient species.

We found no genetic differentiation or distinct lineages for M. bowditchi in relation to different host plants (Fig. 4) despite collecting grasshoppers from populations located more than $230 \mathrm{~km}$ apart (Ardmore, SD and Scottsbluff, NE). We found $\mathrm{G}_{\mathrm{ST}}$ values between 0.06 and 0.2. A

$\mathrm{G}_{\mathrm{ST}}$ value of 1 would indicate nearly complete isolation of subpopulations while 0 indicates no isolation. A G $\mathrm{G}_{\mathrm{ST}}$ value greater than 0.5 indicates some genetic isolation among subpopulations

(Nei 1987). Thus, the low $\mathrm{G}_{\mathrm{ST}}$ in this study reflects the relative measure of variation among subpopulations with reference to total variation (Table 6). In this study, we were unable to identify any clusters in the dendrogram (Fig. 4) that could separate the populations of $M$. bowditchi into distinctive groups.

These results are similar to the conclusions of Brust et al. (2010) who found no genetic differences among M. foedus foedus (Scudder), M. foedus fluviatilis Bruner, and Melanoplus

245 packardii Scudder. Also, Chapco \& Litzenberger (2002), found no genetic differences between 246 M. foedus and M. packardii nor between Melanoplus angustipennis (Dodge) and Melanoplus 
247

248

249

250

251

252

253

254

255

256

257

258

259

260

261

262

263

264

265

266

femurrubrum (De Geer). The Analysis of Molecular Variance indicates that most of the variation

$(86.8 \%)$ was within populations with a small portion $(5.3 \%)$ observed among groups, suggesting

frequent interbreeding. Similarly, the variation among $M$. bowditchi from different host plants

was low, supporting consistent gene flow. The $\mathrm{F}_{\mathrm{ST}}$ value of 0.1320 supports the conclusion that

genetic exchange occurring among the four subpopulations was sufficient to prevent either

genetic differentiation or structuring into genetically differentiated subpopulations of $M$.

bowditchi.

There is support in the literature for host plants resulting in distinct phenotypes. For example, Miller (1987) and Futuyma (1990) documented host-specific phenotypes in papilionid butterflies and Ophraella leaf beetles. The grasshopper specimens in this study were collected as adults feeding on specific plants, and they differed in color and behavior; however, they do not appear to have consistent genetic differences.

The use of the trinomial for M. bowditchi appears invalid; however, we found color morphs that differed in behavior associated with a different hosts and geography. These differences in phenotype appear to be influenced by the environment. These differences are potentially related to the diet, but other environmental factors may play a role. It is further unknown how variable this species is west of the Rocky Mountains. Thus, further detailed investigations for M. bowditchi with morphological and behavioral differences associated with host-plant use should be conducted and the genetic variation among forms should be investigated on a larger scale.

\section{Acknowledgements}

268 We are thankful to Kerri-Farnsworth Hoback for helpful comments on an earlier version of this 269 manuscript. 


\section{Author Contributions}

271 Mathew Brust collected the grasshopper specimens and identified host plants. Muhammad Irfan

272 Ullah dissected grasshoppers and prepared genitalia for examination. Muhammad Irfan Ullah,

273 Fatima Mustafa, and Kate Kneeland prepared specimens for genetic analysis and conducted

274 analyses under the supervision of John E. Foster. W. Wyatt Hoback and Shripat Kamble provided

275 guidance on experimental design and analysis. All authors discussed the results and commented

276 on the manuscript.

277

278

\section{Literature Cited}

Anderson N.L., \& Wright J.C. 1952. Grasshopper investigation on Montana rangelands. Bulletin Montana Agricultural Experiment Station 486: 1-46.

Bruner L. 1897. The grasshoppers that occur in Nebraska. Annual Report Entomology, Nebraska State Building of Agriculture. pp. 105-138.

Brust M.L., Hoback W.W., \& Wright R.J. 2008. A synopsis of Nebraska grasshopper distribution. Journal of the Kansas Entomological Society 81: 208-255.

Brust M.L., Lindroth E.J., Hoback W.W., Wright R.J., Hanford K., \& Foster J.E. 2010. Morphological and genetic analyses in the Melanoplus packardii group (Orthoptera: Acrididae). Journal of Orthoptera Research 19: 281-288.

Chapco W.,\& Litzenberger G. 2002. A molecular phylogenetic analysis of the grasshopper genus Melanoplus Stal (Orthoptera; Acrididae): an update. Journal of Orthoptera Research 11: 19.

Doyle J.J., \& Doyle J.L. 1987. A rapid DNA isolation procedure for small quantities of fresh leaf tissue. Phytochemistry Bulletin 19: 11-15. 
292

293

294

295

296

297

298

299

300

301

302

303

304

305

306

307

308

309

310

311

312

313

314

315

316

317

318

319

320

321

322

323

Eberhard, W.G., \& Huber, B.A., Rodriguez, R.L., Briceno, R.D., Salas, I. and Rodriguez, V. 1998. One size fits all? Relationships between the size and degree of variation in genitalia and other body parts in twenty species of insects and spiders. Evolution 52: 415-431.

Excoffier L., \& Lischer H.E.L. 2010. Arlequin suite ver 3.5: A new series of programs to perform population genetics analysis under Linux and Windows. Molecular Ecology Resources 10: 564-567.

Futuyma D.J. 1990. The evolution of host plant associations in the leaf beetles genus Ophraella (Coleoptera, Chrysomelidae).II. Morphological analyses and evolution of host associations. Evolution. In press

Futuyma D.J., \& Peterson S.C. 1985. Genetic variation in the use of resources by insects. Annual Review of Entomology 30: 217-238.

Harvey S.J. 1981. Life history and reproductive strategies in Artemisia. Bozeman, MT: Montana State University. M.S. thesis. $132 \mathrm{p}$.

Hebard M. 1925. The Orthoptera of South Dakota. Proceedings Academy of Natural Sciences of Philadelphia 77: 35-155.

Hebard M. 1929. The Orthoptera of Colorado. Proceedings of the academy of natural sciences of Philadelphia. 81: 304-425.

Masty, J.P. 170 years of "lock-and-key": genital morphology and reproductive isolation. International Journal of Evolutionary Biology 247352: 1-10.

Miller J.S. 1987. Host-plant relationships in Papilionidae (Lepidoptera): parallel cladogenesis or colonization? Cladistics 3: 105-120.

Mulkern G.B., Pruess K.P., Knutson H., Hagen A.F., Campbell J.B., \& Lambley J.D. 1969. Food habits and preferences of grasshoppers of the north central Great Plains. North Dakota agricultural Experiment Station Bulletin 481.

Nei M. 1987. Molecular Evolution Genetics. Columbia University Press, New York, New York.

Otte D. \& Joern A. 1977. On feeding patterns in desert grasshoppers and the evolution of specialized diets. Proceedings of the Academy of Natural Sciences of Philadelphia 128: $89-126$.

Pfadt R.E. 1994. Field guide to common western grasshoppers, $2^{\text {nd }}$ edition. Wyoming Agricultural Experiment Station Bulletin 912: 1-288.

Pfadt R.E. 2002. A field guide to common western grasshoppers, $3^{\text {rd }}$ edition. Wyoming Agricultural Experiment Station Bulletin 912: 1-288. 
Scudder S.H. 1897. Revision of the orthopteran group Melanopli (Acridiidae), with special reference to North American forms. Proceedings Boston Society of Natural History 20: 1422.

Stanton M.L., \& Cook R.E. 1983. Sources of intraspecific variation in the host plant seeking behavior of Colias butterflies. Oecologia 60: 365-70.

Swofford, D.L. 2001. PAUP (and other methods). Phylogenetic Analysis Using Parsimony. Version 4.0b*. Sinauer, Sunderland, Mass.

Sword G.A., \& Dopman E.B. 1999. Developmental specialization and geographic structure of host plant use in a polyphagous grasshopper, Schistocerca emarginata (-lineata) (Orthoptera: Acrididae).Oecologia 120: 437-445.

Sword G.A., Joern A., \& Senior L.B. 2005. Host plant-associated genetic differentiation in the snakeweed grasshopper, Hesperotettix viridis (Orthoptera: Acrididae). Molecular Ecology 14: 2197-2205.

Tahvanainen J.O., Root R.B. 1972. The influence of vegetational diversity on the population ecology of a specialized herbivore, Phyllotreta cruciferae (Coleoptera: Chrysomelidae). Oecologia 10: 321-46.

Thompson J.N. 1994. The Coevolutionary process. University of Chicago Press, Chicago.

Traxler M.A., \& Joern A. 1999. Performance tradeoffs for two hosts within and between populations of the oligophagous grasshopper Hesperotettix viridis (Acrididae). Oikos. 87: 239-250.

Vos P., Hogers R., Bleeker M., Reijans M., Van de Lee T., Hornes M., Frijters A., Pot J., Peleman J., Kuiper M., \& Zabeau M. 1995. AFLP: a new technique for DNA fingerprinting. Nucleic Acids Research 23: 4407-4414.

Wiklund C. 1975. The evolutionary relationship between adult oviposition preferences and larval host plant range in Papilio machaon. Oecologia 18: 185-97.

Yeh F.C., Yang R., \& Boyle T. 1999. Popgene version 1.32: Microsoft Windows-based freeware for population genetic analysis, University of Alberta, Edmonton, http://www.ualberta.ca/ fyeh/popgene download.html (September 29, 2010). 


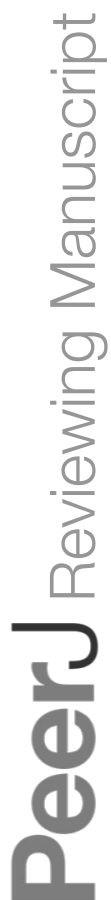

PeerJ reviewing PDF | (v2014:01:1312:1:1:CHECK 16 May 2014) 
352 Table . State, county location, host plant and date of collection for Melanoplus bowditchii 353 specimens used in aedeagus analysis.

\begin{tabular}{|c|c|c|c|c|c|}
\hline State & County & Location & Host Plant & Date & Quantity \\
\hline Nebraska & Dawes & $\begin{array}{l}8 \mathrm{~km} \mathrm{~S} \text { of } \\
\text { Chadron }\end{array}$ & $\begin{array}{l}\text { Fringed sagebrush } \\
\text { Artemisia frigida }\end{array}$ & July 24,2010 & 3 \\
\hline South Dakota & $\begin{array}{l}\text { Fall } \\
\text { River }\end{array}$ & $\begin{array}{l}24 \mathrm{~km} \mathrm{~N} \text { of } \\
\text { Ardmore }\end{array}$ & $\begin{array}{l}\text { Big sagebrush } \\
\text { Artemisia tridentata }\end{array}$ & $\begin{array}{l}\text { August 21, } \\
2010\end{array}$ & 3 \\
\hline Nebraska & Morill & $\begin{array}{l}14.4 \mathrm{~km} \mathrm{SW} \text { of } \\
\text { Alliance }\end{array}$ & $\begin{array}{l}\text { Sand sagebrush } \\
\text { Artemisia filifolia }\end{array}$ & July 24, 2010 & 3 \\
\hline Nebraska & $\begin{array}{l}\text { Scotts } \\
\text { Bluff }\end{array}$ & $\begin{array}{l}12 \mathrm{~km} \mathrm{~N} \text { of } \\
\text { Minatare }\end{array}$ & $\begin{array}{l}\text { Winterfat } \\
\text { Krascheninnikovia } \\
\text { lanata }\end{array}$ & July 17,2010 & 4 \\
\hline
\end{tabular}


354 Table . Collection information for specimens of $M$. bowditchi from different host plants and 355 outgroup, Spharagemon collare used in genetic analysis. Specimens of S. collare were collected 356 with sweep nets from bare soil.

\begin{tabular}{|c|c|c|c|c|c|}
\hline Species & State & County & Location & Host Plant & Date \\
\hline Melanoplus bowditchi & Nebraska & Dawes & $8 \mathrm{~km} \mathrm{~S}$ of Chadron & $\begin{array}{l}\text { Fringed sagebrush } \\
\text { Artemisia frigida }\end{array}$ & $\begin{array}{l}\text { July } 24,2010 \\
\text { August } 7,20\end{array}$ \\
\hline Melanoplus bowditchi & $\begin{array}{l}\text { South } \\
\text { Dakota }\end{array}$ & $\begin{array}{l}\text { Fall } \\
\text { River }\end{array}$ & $24 \mathrm{~km} \mathrm{~N}$ of Ardmore & $\begin{array}{l}\text { Big sagebrush } \\
\text { Artemisia tridentata }\end{array}$ & August 21, 2 \\
\hline Melanoplus bowditchi & Nebraska & Morrill & $\begin{array}{l}17.7 \mathrm{~km} \mathrm{SW} \text { of } \\
\text { Alliance, } 6.4 \mathrm{~km} \text { E of } \\
\text { Broadwater }\end{array}$ & $\begin{array}{l}\text { Sand sagebrush } \\
\text { Artemisia filifolia }\end{array}$ & July 9,2010 \\
\hline Melanoplus bowditchi & Nebraska & $\begin{array}{l}\text { Scotts } \\
\text { Bluff }\end{array}$ & $12 \mathrm{~km} \mathrm{~N}$ of Minatare & $\begin{array}{l}\text { Winterfat } \\
\text { Krascheninnikovia } \\
\text { lanata }\end{array}$ & July 18, 201 \\
\hline $\begin{array}{l}\text { Spharagemon collare } \\
\text { (outgroup) }\end{array}$ & Nebraska & Dawes & $4.8 \mathrm{~km} \mathrm{~S}$ of Chadron & None & August 22, \\
\hline
\end{tabular}


357 Table 3. Nucleotide sequences of adapters, preamplification primers and selective primers used in 358 this study. Sequences were described by Vos et al. (1995).

\begin{tabular}{|c|c|c|}
\hline Oligonucleotide & Purpose & Sequence \\
\hline EcoRI-1 (forward) & Adapter & 5'-CTCGTAGAC' \\
\hline EcoRI-2 (reverse) & Adapter & 5'-AATTGGTAC \\
\hline MseI-1 (forward) & Adapter & 5'-GACGATGAG \\
\hline MseI-2 (reverse) & Adapter & 5'-TACTCAGGA \\
\hline $\mathrm{E}(\mathrm{N}+0)$ & Preamplification Primer & 5'-GACTGCGTA \\
\hline $\mathrm{M}(\mathrm{N}+1)$ & Preamplification Primer & 5'-GATGAGTCC \\
\hline $\mathrm{M}-\mathrm{CAA}$ & Selective Primer & 5'-GATGAGTCC \\
\hline M-CTC & Selective Primer & 5'-GATGAGTCC \\
\hline M-CAG & Selective Primer & 5'-GATGAGTCC \\
\hline E-AAC & Selective Primer & 5'-GACTGCGTA \\
\hline E-ACT & Selective Primer & 5'-GACTGCGTA \\
\hline E-AGG & Selective Primer & 5'-GACTGCGTA \\
\hline E-ACA & Selective Primer & 5'-GACTGCGTA \\
\hline
\end{tabular}


359 Table 4. Selective Primer combinations used for AFLP analysis and number of marker bands 360 obtained for each of six types of four-base pair primer sets.

\begin{tabular}{cccc}
\hline Primer set & EcoRI & MseI & Number of markers \\
\hline 1 & CAAC & ACAA & 93 \\
2 & CAAC & ACAG & 112 \\
3 & CAAC & ACTC & 54 \\
4 & CACA & ACAG & 41 \\
5 & CACT & ACAG & 86 \\
6 & CAGG & ACTC & 83 \\
\hline
\end{tabular}


361 Table 5. Analysis of Molecular Variance (AMOVA) results and fixation indices. Significance was 362 tested with 1,023 permutations. Group 1 was collected from sand sagebrush and fringed 363 sagebrush and Group 2 was collected from winterfat and big sagebrush.

\begin{tabular}{|c|c|c|c|c|}
\hline Among groups & 1 & 200.253 & $4.69095 \mathrm{Va}$ & 5.30 \\
\hline $\begin{array}{l}\text { Among populations } \\
\text { within groups }\end{array}$ & 2 & 257.326 & $6.99008 \mathrm{Vb}$ & 7.90 \\
\hline Within populations & 28 & 2150.327 & $76.79740 \mathrm{Vc}$ & 86.80 \\
\hline Total & 31 & 2607.906 & 88.47843 & \\
\hline \multicolumn{5}{|l|}{ Fixation Indices } \\
\hline
\end{tabular}


366 Table 6. Analysis of Nei's genetic diversity in subdivided populations. Low G $\mathrm{S}_{\mathrm{ST}}$ values suggest 367 diversity among populations, and very high $\mathrm{Nm}$ values $(>1.0)$ indicate significant gene flow 368 between grasshopper populations. Group 1 was collected from sand sagebrush and fringed 369 sagebrush and Group 2 was collected from winterfat and big sagebrush.

\begin{tabular}{lllll}
\hline & $\mathrm{Ht}$ & $\mathrm{Hs}$ & $\mathrm{G}_{\mathrm{ST}}$ & $\mathrm{Nm}$ \\
\hline Group 1 & 0.2843 & 0.2266 & 0.2030 & 1.9630 \\
Group 2 & 0.2862 & 0.2665 & 0.0690 & 6.7499 \\
All populations & 0.3127 & 0.2853 & 0.0879 & 5.1905 \\
\hline
\end{tabular}

$370 \mathrm{Ht}=$ Total diversity

$371 \mathrm{Hs}=$ Diversity within populations

$372 \mathrm{G}_{\mathrm{ST}}=$ Diversity among populations

$373 \mathrm{Nm}=$ Estimate of gene flow based on $\mathrm{G}_{\mathrm{ST}}$ 


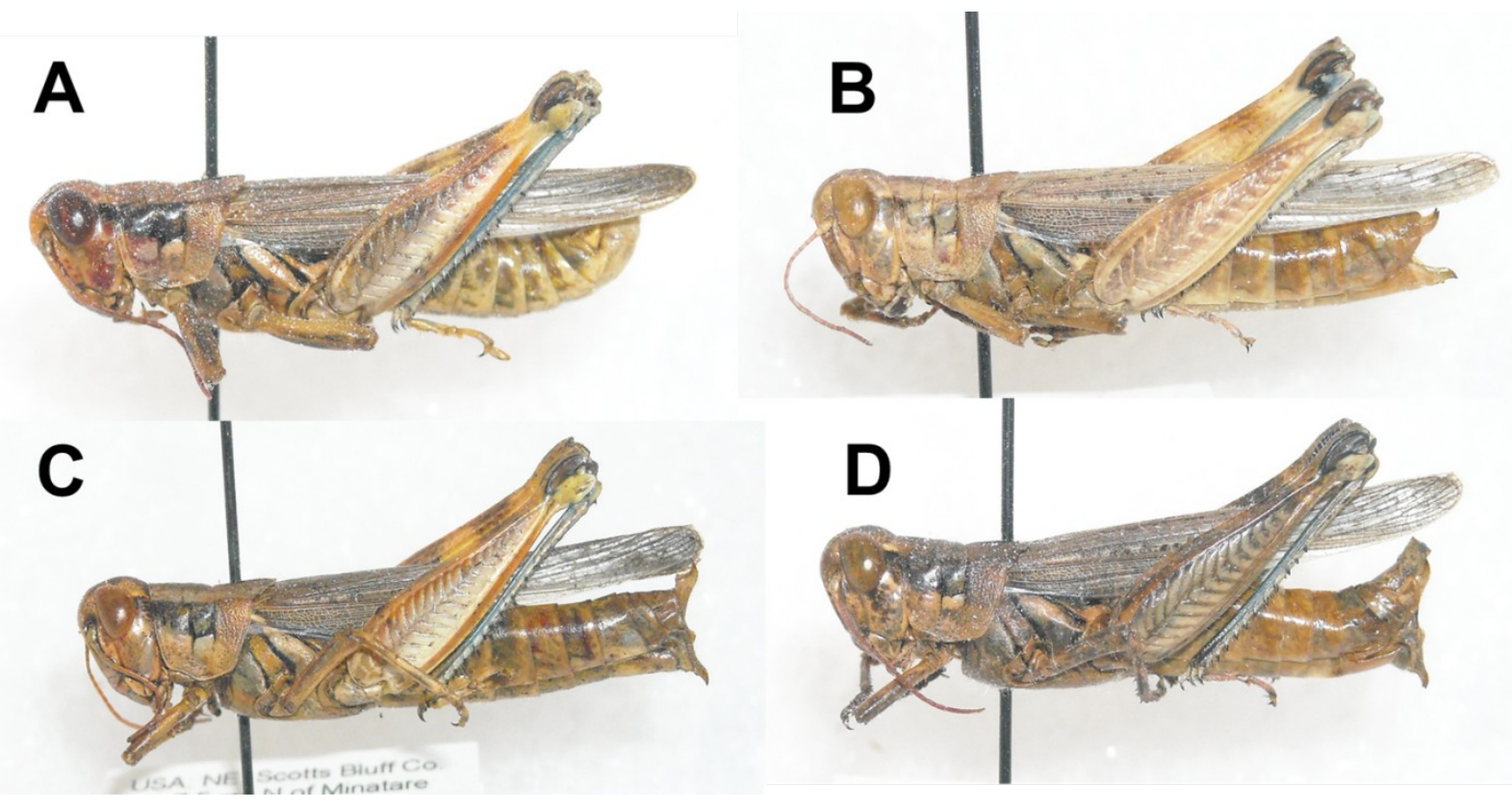

374 Figure 1. Lateral view of Melanoplus bowditchii grasshoppers collected feeding on A) sand 375 sagebrush, B) fringed sagebrush, C) winterfat, and D) big sagebrush. 


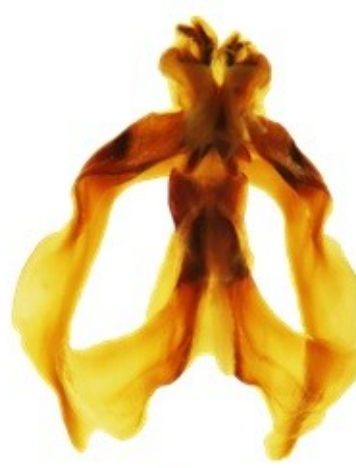

a

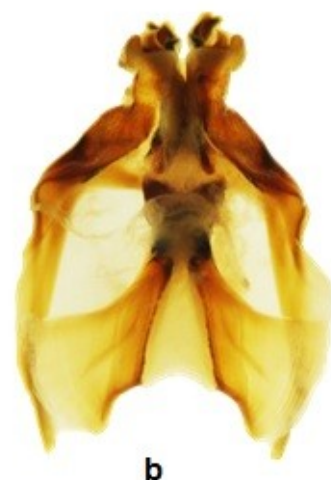

b
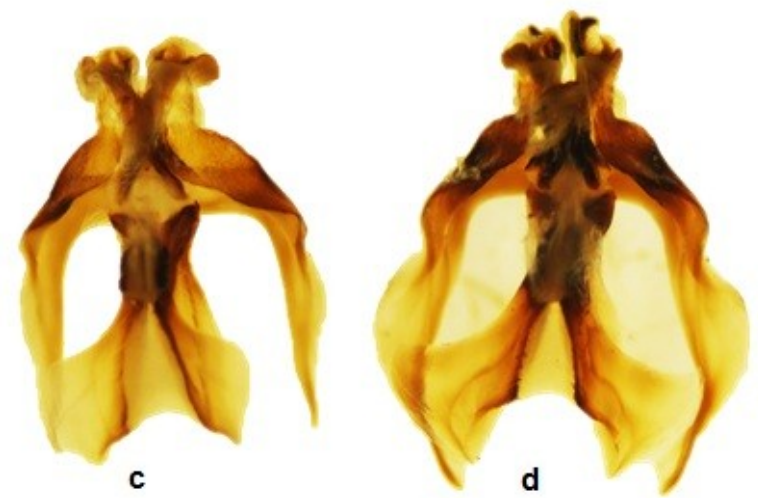

376 Figure 2. Dorsal view of the aedeagus of Melanoplus bowditchi collected from (a) sand 377 sagebrush, (b) fringed sagebrush, (c) winterfat, and (d) big sagebrush. 


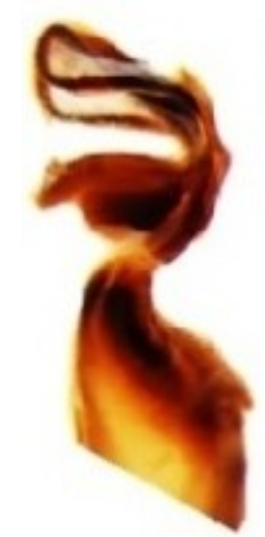

A

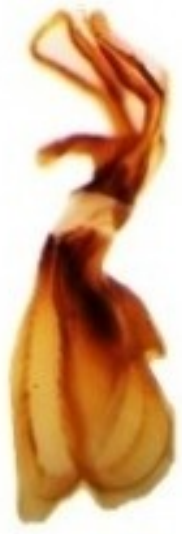

$\mathrm{B}$

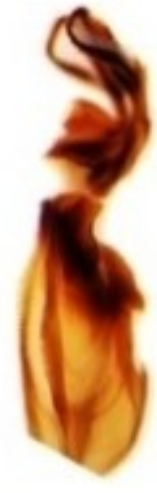

$\mathrm{C}$

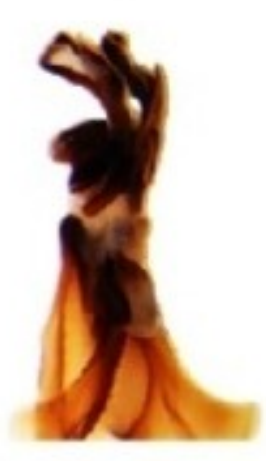

$\mathrm{D}$

Figure 3. (A) Lateral view of the aedeagus of Melanoplus bowditchi collected from (a) sand 380 sagebrush, (b) fringed sagebrush, (c) winterfat, and (d) big sagebrush.. 


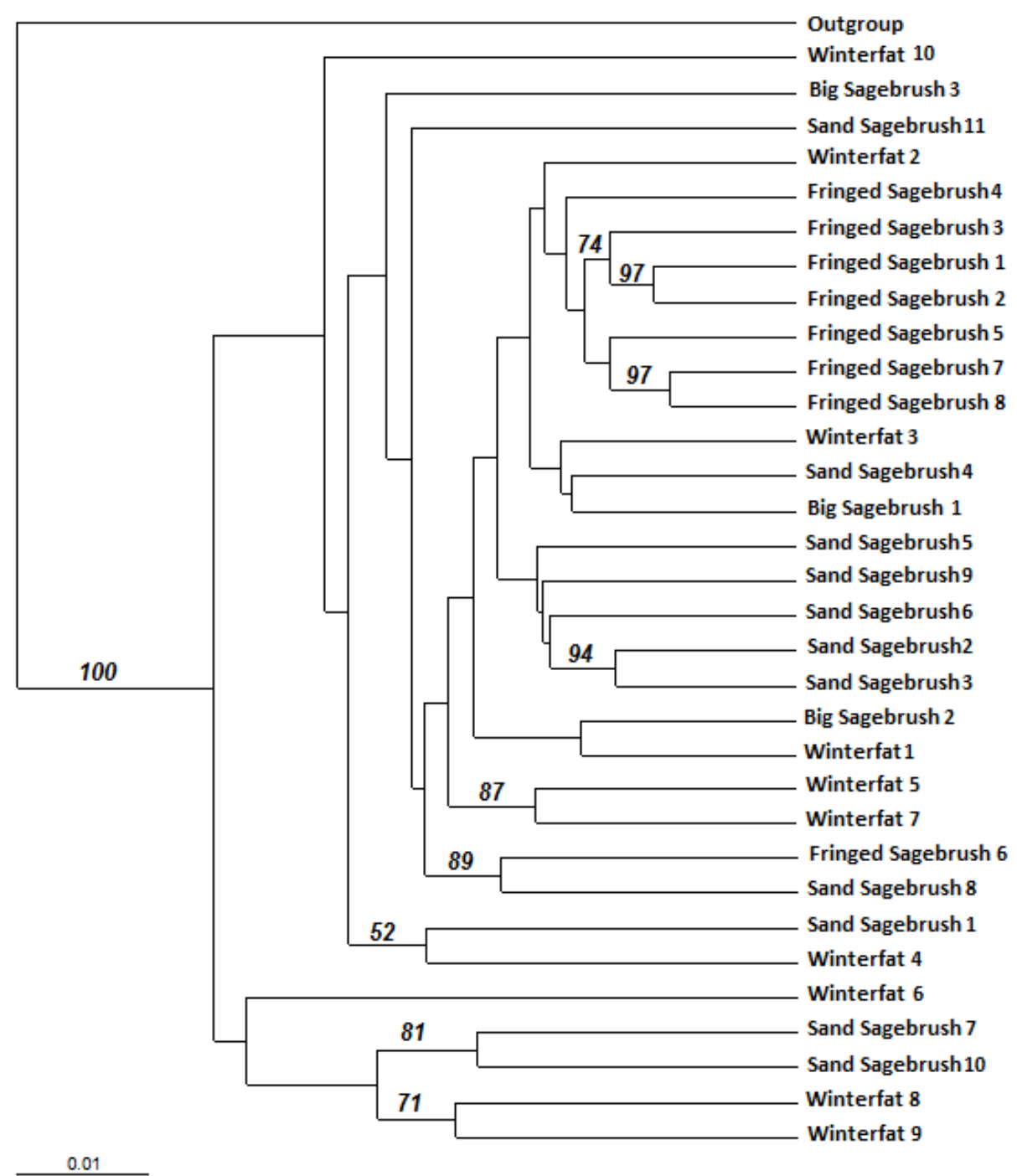

381 Fig. 4. Distance-based Unweighted Pair Group Method with Arithmetic mean (UPGMA) dendrogram of $M$. bowditchi grasshoppers using 1,000 bootstrap replicates. The dendrogram shows the relationship among individuals. Numbers indicate bootstrap support $>50 \%$ for populations collected from different host plants. 


\section{Figure 1}

Lateral view of Melanoplus bowditchii grasshoppers collected feeding on A) sand sagebrush, B) fringed sagebrush, C) winterfat, and D) big sagebrush
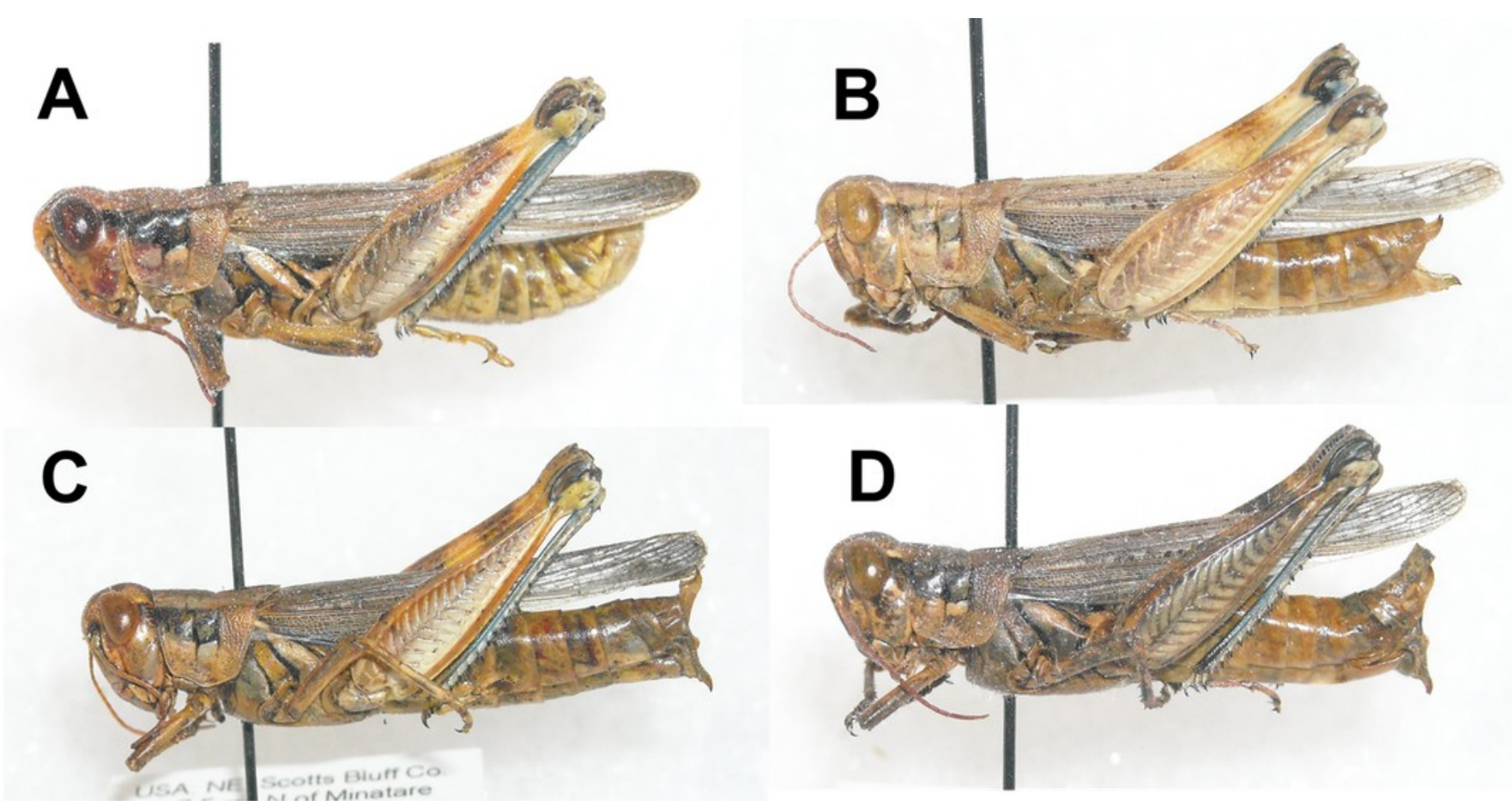


\section{Figure 2}

Dorsal view of the aedeagus of Melanoplus bowditchi collected from (a) sand sagebrush, (b) fringed sagebrush, (c) winterfat, and (d) big sagebrush

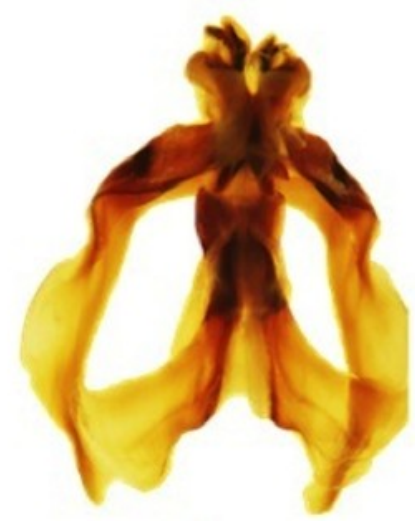

a

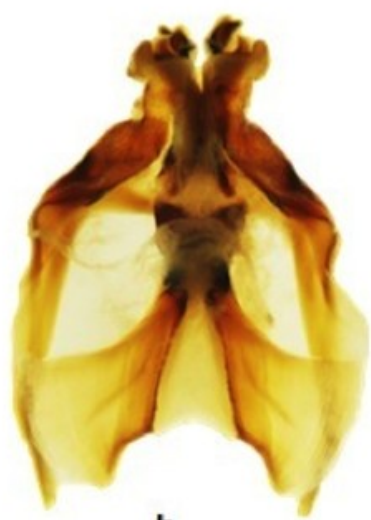

b

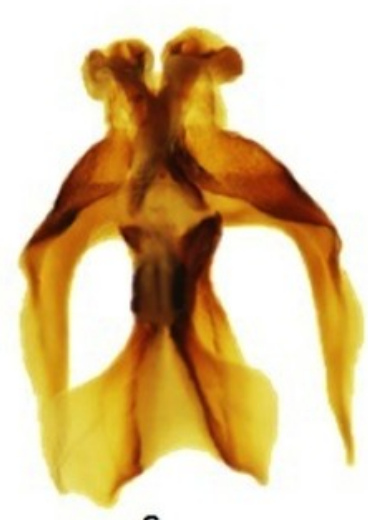

c

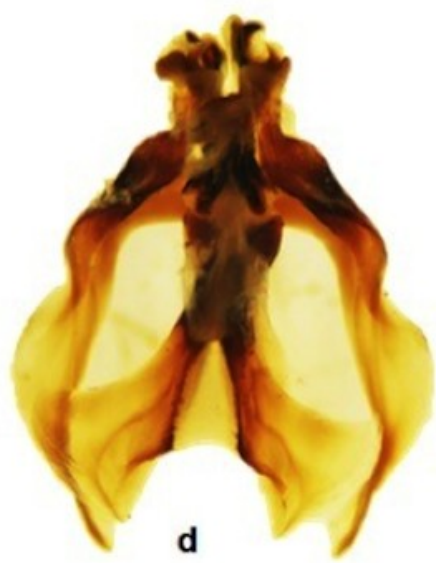




\section{Figure 3}

Lateral view of the aedeagus of Melanoplus bowditchi collected from (A) sand sagebrush, $(B)$ fringed sagebrush, $(C)$ winterfat, and (D) big sagebrush
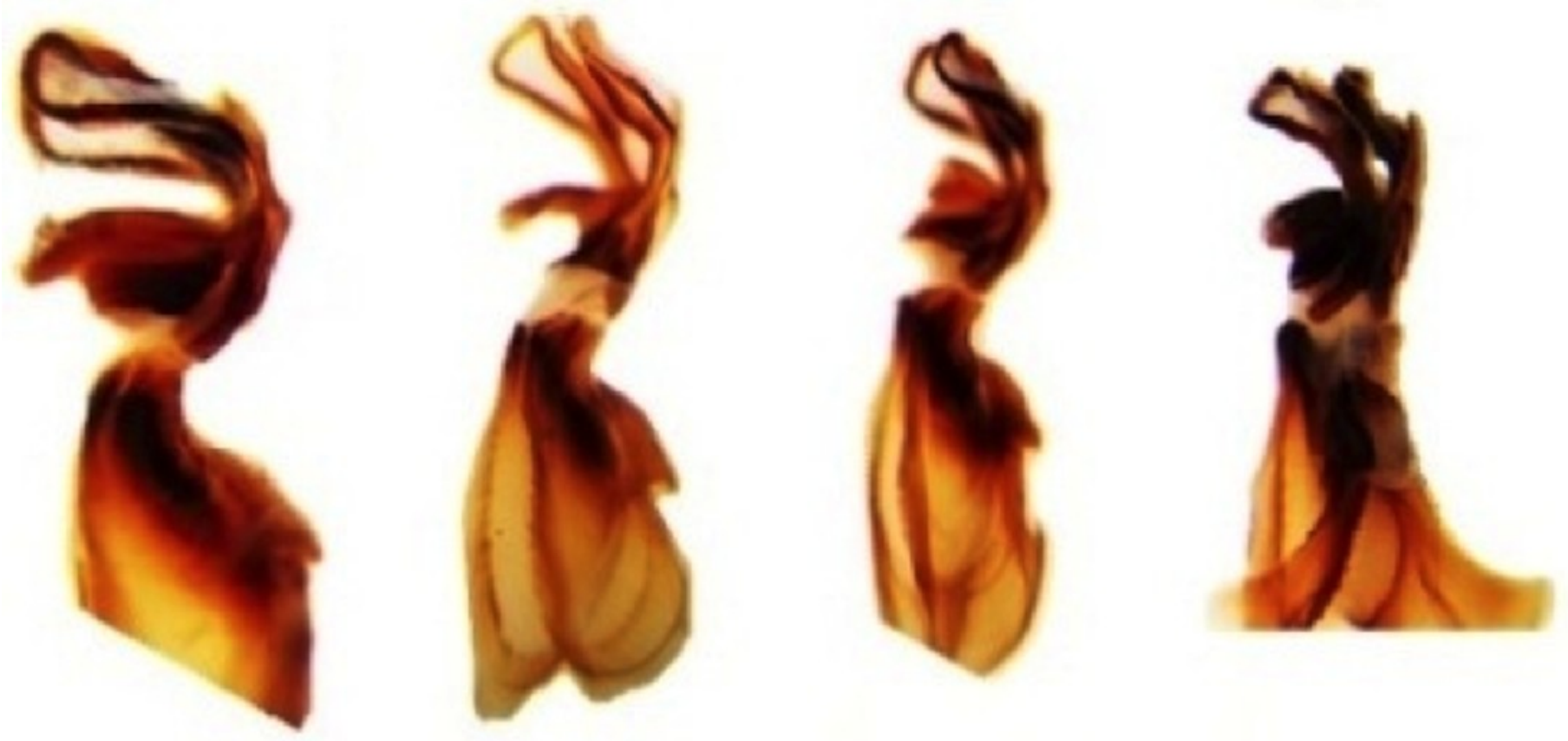


\section{Figure 4}

Distance-based Unweighted Pair Group Method with Arithmetic mean (UPGMA) dendrogram of $M$. bowditchi grasshoppers using 1,000 bootstrap replicates.

The dendrogram shows the relationship among individuals. Numbers indicate bootstrap support $>50 \%$ for populations collected from different host plants

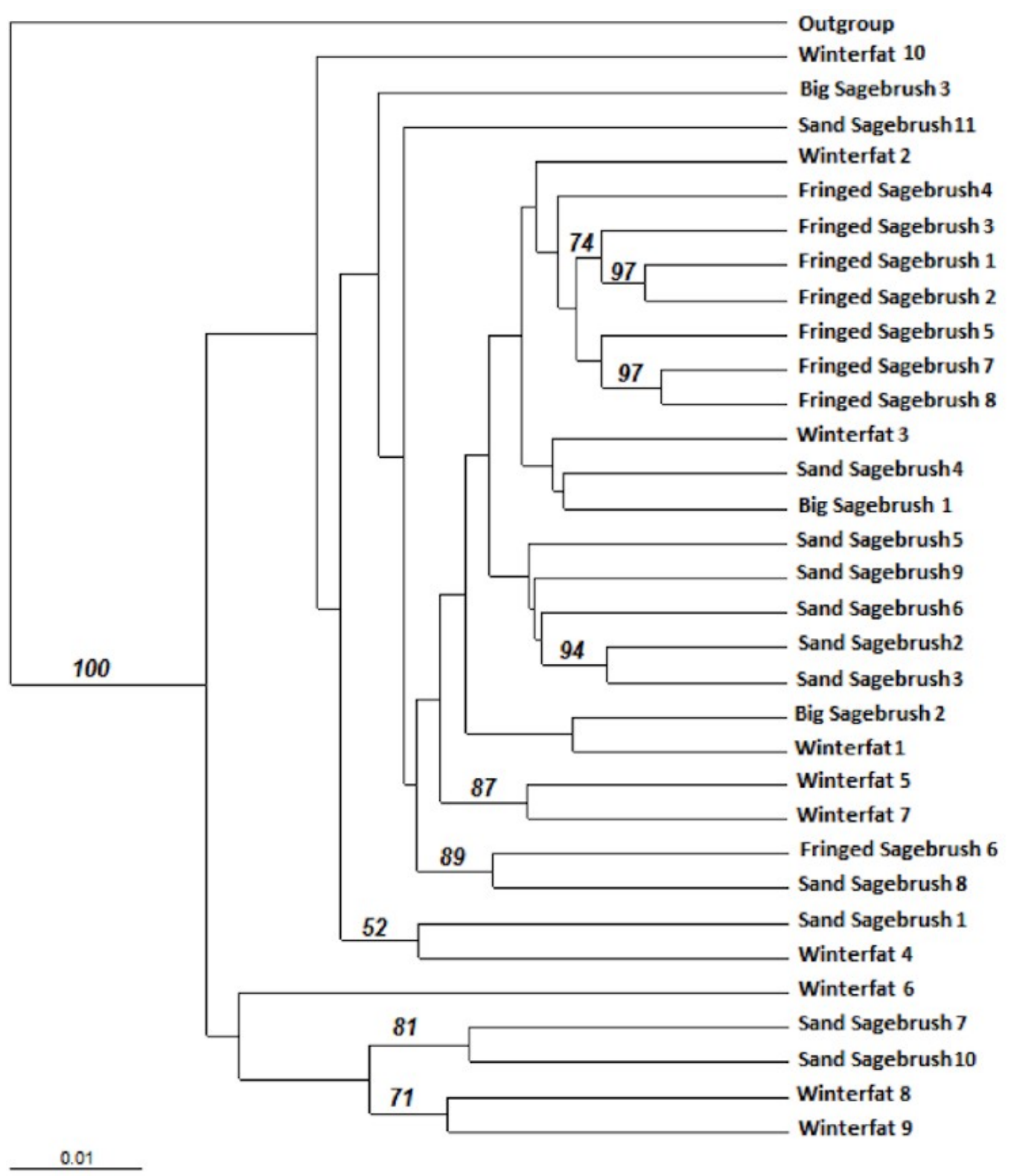




\section{Table 1 (on next page)}

State, county location, host plant and date of collection for Melanoplus bowditchii specimens used in aedeagus analysis. 


\begin{tabular}{|c|c|c|c|c|c|}
\hline State & County & Location & Host Plant & Date & Quantity \\
\hline Nebraska & Dawes & $\begin{array}{l}8 \mathrm{~km} \mathrm{~S} \text { of } \\
\text { Chadron }\end{array}$ & $\begin{array}{l}\text { Fringed sagebrush } \\
\text { Artemisia frigida }\end{array}$ & July 24,2010 & 3 \\
\hline South Dakota & \begin{tabular}{|l} 
Fall \\
River
\end{tabular} & $\begin{array}{l}24 \mathrm{~km} \mathrm{~N} \text { of } \\
\text { Ardmore }\end{array}$ & \begin{tabular}{|l} 
Big sagebrush \\
Artemisia tridentata
\end{tabular} & \begin{tabular}{|l} 
August 21, \\
2010
\end{tabular} & 3 \\
\hline Nebraska & Morill & $\begin{array}{l}14.4 \mathrm{~km} \mathrm{SW} \text { of } \\
\text { Alliance }\end{array}$ & \begin{tabular}{|l|} 
Sand sagebrush \\
Artemisia filifolia
\end{tabular} & July 24,2010 & 3 \\
\hline Nebraska & $\begin{array}{l}\text { Scotts } \\
\text { Bluff }\end{array}$ & $\begin{array}{l}12 \mathrm{~km} \mathrm{~N} \text { of } \\
\text { Minatare }\end{array}$ & \begin{tabular}{|l} 
Winterfat \\
Krascheninnikovia \\
lanata \\
\end{tabular} & July 17,2010 & 4 \\
\hline
\end{tabular}




\section{Table 2 (on next page)}

Collection information for specimens of $M$. bowditchi from different host plants and outgroup, Spharagemon collare used in genetic analysis.

Specimens of S. collare were collected with sweep nets from bare soil. 


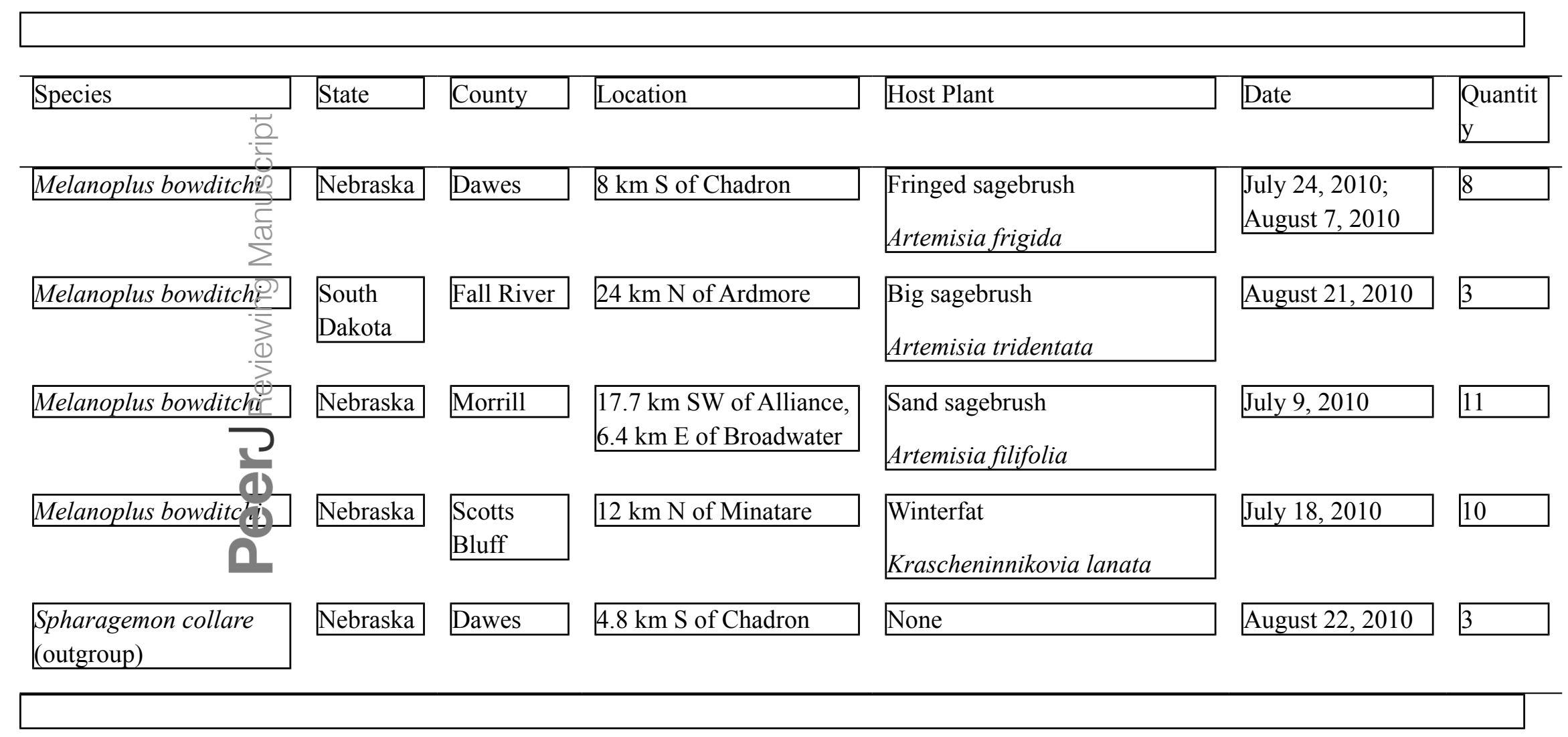




\section{Table 3 (on next page)}

Nucleotide sequences of adapters, preamplification primers and selective primers used in this study. Sequences were described by Vos et al. (1995). 


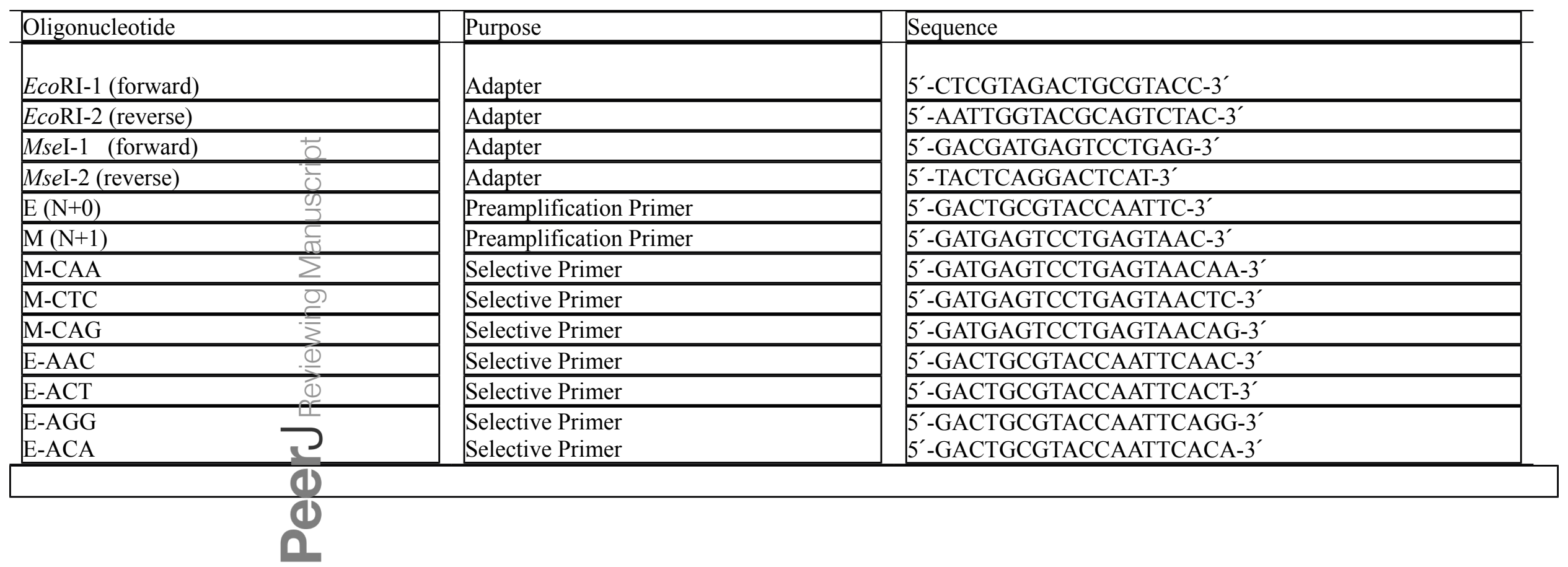




\section{Table 4 (on next page)}

Selective Primer combinations used for AFLP analysis and number of marker bands obtained for each of six types of four-base pair primer sets. 


\begin{tabular}{|c|c|c|c|}
\hline Primer set & EcoRI & MseI & Number of markers \\
\hline 1 & CAAC & ACAA & 93 \\
\hline 2 & CAAC & $\mathrm{ACAG}$ & 112 \\
\hline 3 & CAAC & ACTC & 54 \\
\hline 4 & $\overline{C A C A}$ & $\overline{\mathrm{ACAG}}$ & $\overline{41}$ \\
\hline 5 & CACT & $\mathrm{ACAG}$ & 86 \\
\hline 6 & CAGG & ACTC & 83 \\
\hline
\end{tabular}




\section{Table 5 (on next page)}

Analysis of Molecular Variance (AMOVA) results and fixation indices.

Significance was tested with 1,023 permutations. Group 1 was collected from sand sagebrush and fringed sagebrush and Group 2 was collected from winterfat and big sagebrush. 


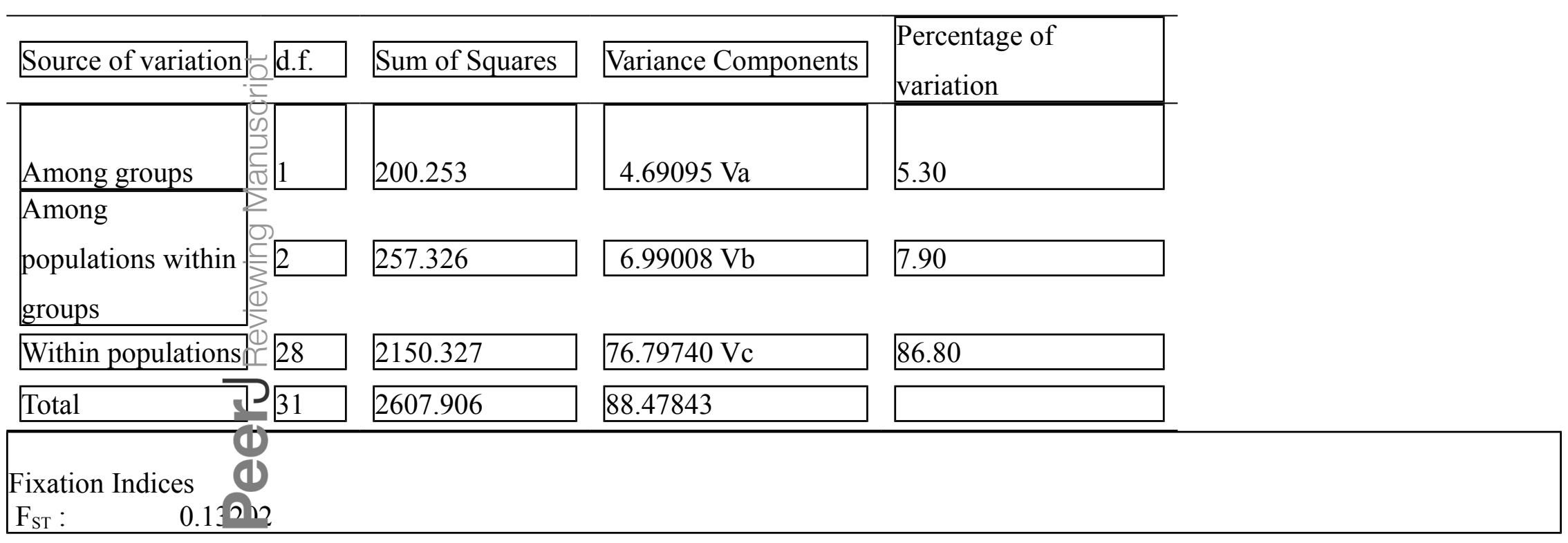




\section{Table 6 (on next page)}

Analysis of Nei's genetic diversity in subdivided populations.

Low $\mathrm{G}_{\mathrm{ST}}$ values suggest diversity among populations, and very high $\mathrm{Nm}$ values $(>1.0)$ indicate significant gene flow between grasshopper populations. Group 1 was collected from sand sagebrush and fringed sagebrush and Group 2 was collected from winterfat and big sagebrush. 


\begin{tabular}{|llll|l|}
\hline Ht & Hs & $\mathrm{G}_{\mathrm{ST}}$ & $\mathrm{Nm}$ & \\
\hline Group 1 & 0.2843 & 0.2266 & 0.2030 & 1.9630 \\
Group 2 & 0.2862 & 0.2665 & 0.0690 & 6.7499 \\
All populations & 0.3127 & 0.2853 & 0.0879 & 5.1905 \\
\hline \\
Ht = Total diversity & & \\
Hs = Diversity within populations & & \\
GsT = Diversity among populations & & \\
Nm = Estimate of gene flow based on G & & \\
& & & \\
\end{tabular}

